\title{
The Firm-Specific Determinants of the Target Capital Structure: Evidence from Bosnia and Herzegovina Panel Data
}

\author{
Jasmina Mangafić \\ School of Economics and Business, University of Sarajevo, Sarajevo, Bosnia and Herzegovina \\ jasmina.mangafic@efsa.unsa.ba \\ Danijela Martinović \\ School of Economics and Business, University of Sarajevo, Sarajevo, Bosnia and Herzegovina \\ danijela.martinovic@efsa.unsa.ba
}

\section{Doi:10.5901/mjss.2015.v6n2s5p188}

\section{Abstract}

The purpose of this study is to carry out a comprehensive and robust analysis of the determinants of the capital structure of the Federation Bosnia and Herzegovina (FBiH) companies at the industry level. A large number of hypotheses of different classes of theories are tested. Estimating the dynamic panel models using the system of generalized method of moments (GMM) estimator, we captured both cross-sectional and inter-temporal relationships between the leverage in companies and its determinants. The results show that profitability, collateral value of the assets and the risk, measured by earnings volatility, negatively affect company's leverage, while inconsistent results were for the relationship between different proxies for firm's future growth opportunities and leverage, whereby the firm size overall has no relationship with the firm' $s$ leverage. The findings reflect the transitional nature of the FBiH corporate environment. They suggest that some of the insights from modern finance theory of capital structure are applicable in the FBiH in that certain firm-specific factors that are relevant for explaining capital structure in developed economies are also relevant in the FBiH. Overall, the empirical evidence presented in this Study finds it difficult to demonstrate the validity of the trade-off and the pecking order theories as stand-alone models. The Study's results also point at several unique aspects of financing behavior in developing countries, from which specific implications for further research follow.

Keywords: capital structure, transition economy, pecking order theory, trade-off theory

\section{Introduction}

Determinants are variables successfully used as leverage predictors. A large number of factors have been identified in the extent literature that influence the financing decisions of companies based on financial theories of capital structure.However, there is no consensus in the literature whether such theories adequately explain the capital structure adopted by firms in the context of developing economies. Therefore, this chapter empirically investigates the effects of firm-specific determinants on firms 'capital structure. Of course, for a number of reasons, we would expect the capital structure to vary considerably across industries and moreover, for the capital structure to vary among firms within a given industry. In an attempt to clarify those variations, the academics and practitioners have developed a number of theories and the theories have been subjected to many empirical tests.

This Study is an attempt to give a comprehensive and robust analysis of the determinants of the capital structure of $\mathrm{FBiH}$ firms at the industry level to reveal the differences between the industries in the capital structure during the period of ten years including the economic up - and down turns. The empirical analysis focused on 10 years (2003-2012) of the data on a sample of private non financial companies in order to test the relationship between the capital structure and the leverage determinants, combining all variables affecting the determination of the capital structure. The explanatory variables included in the model vary across both firms and time and in our empirical investigation we use two capital structure measures.

This Study will answer the question as to which factors determine the capital structure of FBiH companies and whether existing financial theories of capital structure hold true in that context. The determinants of the capital structure decisions should guide companies on how to choose their strategic financing mix. In other words, this research results may draw the attention on those factors, which are worth considering if the corporate structure is determined. Those 
findings will certainly advance our understanding of a firm's financing behavior.

Such a Study would contribute to the current references in several ways. Firstly, as far sa we are aware, it is the first attempt at a direct testing of the affect of company variables on the capital structure decisions in the companies in the $\mathrm{FBiH}$. Secondly, despite the fact that there is evidence that features of an industry do matter in the capital structure decisions of companies, we are yet to find a study that examines variations across industries in the capital structure decisions in the companies in FBiH. To our knowledge, there no empirical work that focuses on inter-industry variation in the financing decision of firms in FBiH. As in other developing countries, FBiH government sometimes institute policy interventions to foster investment in certain sectors/industries by way of subsidies and directed credit. Understanding the place of the industry factor in the financing decisions of a firm is crucial for the purpose of crafting appropriate policy interventions. In the context of FBiH, there is no published work that investigates the dynamic partial adjustment of a firm's capital structure. This chapter aims to fill this gap by investigating whether firms in our sample adjust their capital structures to a certain target level.

The remainder of this chapter proceeds as follows. The next section lays out the firm-level determinants of capital structure. Section 3 provides explains the construction of variables, with the specification of the hypothesis presents the research methodology and models and discusses the empirical models. Section 4 reports the statistical analysis and empirical results. The findings and conclusions are presented in the last section.

\section{Empirical Literature Review}

The firm's capital structure can be determined through several factors. Those observable elements for leverage should be linked to the theories on the capital structure since they are the assumed proxy for the forces that underpin theories, such as the financial distress and information asymmetry costs. However, the this relationship is not always clear, and hence it is important to resolve the elements that are reliable and economically important in order to predict the leverage. Some of the attributes which affect the choice of capital structure are the same for firms within the same industry. However, the effects of some of these attributes, for example, type of output market and type of products, are not testable because these attributes themselves are not easily measurable. Therefore, in the table below the existing theoretical framework are set out to explain the determinants of the capital structure.

Table 1. Summary of the Capital Structure Theories Predictions

\begin{tabular}{|c|l|c|c|c|c|}
\hline \multirow{2}{*}{ No } & \multirow{2}{*}{ Variables } & \multicolumn{2}{|c|}{ Static trade-off theory } & \multicolumn{2}{c|}{ Asymmetric information theory } \\
\cline { 3 - 6 } & & TBT & Agency & POT & ST \\
\hline 1 & Firm Size & + & + & - & + \\
\hline 2 & Profitability & + & + & - & + \\
\hline 3 & Growth opportunity & - & - & + & + \\
\hline 4 & Asset tangibility & + & + & $+/-$ & \\
\hline 5 & Tax shield & - & & & \\
\hline 6 & Risk & - & + & - & \\
\hline 7 & Dividend policy & & - & + & $+/-$ \\
\hline $\mathbf{8}$ & Uniqueness of product & - & & & \\
\hline 9 & Managerial equity ownership & & - & + & $+/-$ \\
\hline
\end{tabular}

Source: H. Asgharian, Essays on capital structure, 1997, p.41

Note: The table shows the expected effects of different attributes on capital structure, as implied by the capital structure theories. TBT refers to the tax-bankruptcy static trade off theory. POT denotes the pecking order theory. ST refers to the signalling theory. The $+(-)$ sign shows the expected positive (negative) relationship between the leverage and the designated variable. The (+/-) sign signifies the possibility that plausible arguments could be made for a positive as a negative relationship using a given theory. ${ }^{*}$ The profitability has a positive sign for Static trade of theory, whether the Dynamic one foresees the negative sign.

Fifty years after Modigliani and Miller's (1958) made their ground-breaking analysis, there is yet no unifying theory on the capital structure for the corporate finance. Despite this, the applicable theories serve as analytical tools in order to probe the empirical findings. However, none are capable of explaining all the aspects in the capital structure choice. Even though some of the stylized facts can be successfully accounted for in each theory, there are incongruities with some of 
the others. The current reference materials say that the most reliable elements explaining the corporate leverage are the market-to-book ratio $(-)$, tangibility $(+)$, profitability $(-)$, company size $(+)$, expected inflation $(+)$, and median industry leverage (+ effect on leverage). Frank and Goyal (2009) refer to these factors as the "core leverage factors" affecting the decisions on the capital structure. On the sample of publicly traded U.S. firms from 1950-2003, they examined an extensive list of elements which could arguably reason why there is heterogeneity between capital structures across companies. With a market-based definition of leverage, they found out that those six factor account for more than $27 \%$ of the variation in leverage, while another 19 factors improve the explanatory power of the model by only $2 \%$. Furthermore, those six core factors provide a more powerful explanation of a market-based definition of leverage than a book-based definition of leverage. According to the authors if focus would be on a book-based definition of leverage, the market-tobook ratio, firm size and expected inflation would have all have been excluded from the core model (Bessler, et.al, 2011).

The table below provides the summary of selected empirical findingsregarding the relationship between chosen firm-specific characteristics and leverage.

Table 2. Summary of Empirical Evidence from Selected Empirical Studies

\begin{tabular}{|c|c|c|c|c|c|}
\hline \multicolumn{6}{|c|}{ Summary of empirical evidence from selected empirical studies } \\
\hline \multirow{2}{*}{ Study } & \multicolumn{5}{|c|}{ Determinants of capital structure } \\
\hline & Firm size & Profitability & Growth opportunity & Asset tangibility & Risk \\
\hline Bradley et.al (1984) & & & & + & - \\
\hline Kim and Sorensen (1986) & & & - & & + \\
\hline Kester (1986) & & - & + & & * \\
\hline Friend and Lang (1988) & * & - & & + & * \\
\hline Rajan and Zingales (1995) & + & - & - & + & - \\
\hline Asgharian (1997) & + & - & + & + & \\
\hline Titman and Wessels (1998) & - & $+/-$ & * & * & * \\
\hline Shyam-Sunder and Myers (1999) & & - & & + & - \\
\hline Fan, Titman and Twite (2003) & + & - & - & + & \\
\hline Flannery and Rangan (2006) & + & - & * & + & \\
\hline Antoniou et.al (2008) & + & - & - & + & * \\
\hline Talberg et. al (2008) & - & - & - & + & \\
\hline Clark et al. (2009) & + & * & & * & \\
\hline Chang et al. (2009) & & $+/-$ & $+/-$ & $+/-$ & $+/-$ \\
\hline Frank and Goyal (2009) & + & - & - & + & \\
\hline
\end{tabular}

The $+(-)$ sign indicates a significant positive (negative) relationship between leverage ratio and the capital structure determinant. The * designates an included but insignificant variable in the model. Empty cells mean that there was no testing of the variable.

Anotherimportant remark to be done is those "six core factors" together only explain about $25 \%$ of the total variation. Additionally a recent paper of Lemmon, Roberts and Zender, (2008) argues that determinants of traditional leverage explain a minor part of the leverage variation (30\% at most), while $60 \%$ is yet to be explained. The foregoing variation stemming from an unobserved firm-specific, time-invariant component responsible for the persistence of leverage ratios over time. Due to the fact that the authors focused on the economy in the US, which can be considered as relatively stable economy, it is actually unclear if the leverage ratios show a similar level of persistence if there are rapid changes in the economic environment over time (Shamshur, 2012). Therefore, a Study like this one, is more than welcome when carried out using the example of a transitional economy.

The theory of capital structure has developed considerably in the last ten years, but empirical work is still far from analyzing all the implications of the theories. Research into the empirical corporate finance gave many studies that tried to identify those elements which are driving the company's capital structure. The evidence on the capital structure determinants is strong between companies and various countries. These studies greatly differ in terms of the sample selection, variable definition, sample period, sample size, and the econometric methodology.

Obviously, there is no uniformity when it comes to the theoretical predictions or empirical results. Empirical research has been restricted by difficulties in finding appropriate proxies for attributes which are supposed to determine the capital structure of a company. In addition, the use of book versus market value for measuring the firm's equity and assets differs among studies.

Consistent with the above-mentioned study, but having in mind the availability of data required to calculate those 
variables, this Study includes a following set of firm level variables that capture the factors that are known to affect the capital structure: the firm size, profitability, growth opportunities, asset tangibility and earnings volatility. What follows is a brief description of each of them and the development of hypothesis in accordance with the dynamic tradeoff theory.

Namely, recent literature critiques the studies on determinants of capital structure on the grounds that they do not take into account the typical rebalancing behavior of firms as far as their capital structure is concerned. It draws on dynamic trade-off theory and develops a theory for dynamic capital structure (Flannery \& Hankins 2007). We may group the literature on the study of dynamic capital structure into two succinct clusters: (i) those investigating whether firms adjust towards a target capital structure; and (ii) those investigating the factors that influence the pace at which firms adjust their capital structure. This Study analyses the first one.

\section{The Empirical Framework}

The empirical analysis focused on 10 years (2003 - 2012) data pertaining to a sample of non-financial firms in Federation of Bosnia and Herzegovina $(\mathrm{FBIH})$. The current study examines the influence of firm level factors in the determination of basic capital structure. As this Study involves an examination of the determinants of inter-industry differences, the firmspecific data used for the analyses in this chapter was extracted from the financial statements of non-financial, privately owned, listed as non-listed firms in $\mathrm{FBiH}$. The analysis carries out both for the entire sample and for the individual industries.

The main research objectiveisto estimate the effects of firm's level determinants on their capital structure measures in different industries.Considering the research objective, the relevant research question is whether the stylized relation between capital structure measures and several firm level variables obtained from the literature can be generalized to firms in FBiH. This brings us to the following hypotheses:

$\checkmark$ Firm level variables such as the firm size, profitability, growth opportunity, asset tangibility, risk are statistically significant determinants of capital structure measures.

Most of the research studies on capital structure have used the data from the US and European companies. This Study provides a unique opportunity to examine the validity of the above statements and whether the capital structure of $\mathrm{FBiH}$ firms can be explained by the finance theory. Survival and growth necessitates the resources, but financing of these resources has its limits.

\subsection{Econometric Framework}

A panel data analysis may capture both cross-sectional and inter temporal relationships between firm leverage and its determinants. Given that our empirical models have a dynamic paneldata context, we use the robust two-step system dynamic panel data estimator also known as "system GMM" estimator-proposed by Blundell and Bond (1998). In contrast to the conventional ordinary least square (OLS), Within-Groups and first-difference GMM estimators, the system GMM estimator not only mitigates potential endogeneity problems, controls for heterogeneity across individual firms, and removes unobserved firm-specific fixed effects, but it also allows researchers to make use of different instruments with different lag structure for both the levels and the first-differenced equations (Blundell \&Bond,1998, 2000; Bond, 2002).

Arellano and Bond (1991) suggest using a dynamic panel data estimator based on the GMM methodology that optimally exploits the linear moment restrictions implied by the dynamic panel model. GMM estimator uses both lagged values of all endogenous regressors and lagged and current values of all strictly exogenous regressors as instruments. Models can be estimated using the levels or the first differences of the variables. For the difference estimator, the variables are measured as first differences and their lagged values are used as appropriate instruments.

The Arellano-Bover/Blundell-Bond (Arellano \&Bover, 1995; Blundell \& Bond, 1998) dynamic panel estimator augments Arellano-Bond by making an additional assumption that first differences of instrument variables are uncorrelated with the fixed effects. According to this estimator, the lagged levels of variables are likely to be weak instruments for current differenced variables when the series are close to random walk. In these conditions, the differenced GMM estimates are likely to be biased and inefficient. The authors suggest the use of a more efficient system GMM estimator that combines the difference-equation and a levels-equation in which suitably lagged differenced variables are the appropriate instruments. It builds a system of two equations (the original and the transformed one) and is known as system GMM. The xtabond2 command implements these estimators (Roodman, 2009).

We applied the Hansen (1982) test for over identifying restrictions and the Arellano and Bond (1991) test for autocorrelation to ensure the validity of the instruments that we use in our estimations. More precisely, to test for the validity of the instruments, we use the J-statistic of Hansen (1982). This statistic is asymptotically distributed as X2 with 
degrees of freedom equal to the number of over identifying restrictions (i.e., the number of instruments less the number of estimated parameters). Under the null hypothesis, the instruments are orthogonal to the errors. We employ the Arellano and Bond (1991) test for autocorrelation. Under the null of no serial correlation, the test asymptotically follows a standard normal distribution. It also provides a further check on the correct specification of the System-GMM process. In a dynamic panel data context, the first-order serial correlation is likely to be present, but the residuals should not exhibit the second-order serial correlation if the instruments are strictly exogenous.

\subsection{Operationalisation of Variables}

For the purpose of this study we have chosen to measure leverage by two variables (Welch, 2011):

[pcs1] the financial-debt-to-capital ratio (financial leverage) that does not consider non-financial liabilities as debt

- [pcs3 ]the total-liabilities-to assets ratio (balance sheet leverage) that treats financial and non-financial liabilities alike

There are five variables expected to be important as determinants of the capital structure. The remainder of this section discusses the exogenous variable and their proxies.

To control for any possible heteroscedasticity, the natural logarithm is used, while to ensure linearity in the data, due to its capabilities to standardize values thus, bringing them on the same platform for a more efficient analysis to be done:

- $\quad$ pfsa] natural logarithm of the total assets (Padron et al., 2005)

- [pfsr] natural logarithm of the total revenue (Titman \&Wessels, 1988; Rajan\&Zingales, 1995; Wiwattanakantang, 1999; Graham, 2000; Ozkan, 2001; Gaud et al., 2005)

- [pfse]natural logarithm of the number of employees (Asgharian, 1997).

We use following ratios to measure profitability:

- [pp1]the return-on-total assets ratio (ROTA) that measures a company's earnings before interest and taxes (EBIT) against its total net assets (Rajan\&Zingales,1995; Ooi,1999; Ozkan,2001; Gaud et al.,2005)

- [pp2]the return-on-assets ratio (ROA) that measures a company's net income against its total net assets (Wiwattanakantang,1999)

The proxies for the growth opportunity include as follows:

- [pg1] the ratio of difference in the book value of total asset between yeart-1 and yeart divided by the book value of the total assets in yeart-1 (Titman \&Wessels,1988; Ooi,1999; Chen,2004)

- [pg2] the ratio of difference in total revenues between yeart-1 and yeart divided by total revenues in yeart-1 (Asgharian, 1997)

- [pg3] the ratios above are based on a two-year difference in values; we also estimated growth using information spanning several years. We run the regression of book value of total assets over ten years on a time trend and use the coefficient of the trend, scaled by the book value of the total assets, as a proxy for growth (Asgharian, 1997)

We use the following indicators to measure collateral and/or liquidation value of assets (assets tangibility) which are considered to be good candidates for borrowing.

- [pat1] the ratio of tangible/physical assets to total assets; this measure is the most common one applied to determine the collateral value of the assets (Asgharian, 1997). This measurement is expected to be positively related to the collateral value of the assets.

- [pat2] the ratio of tangible/physical assets to total assets; Some intangible assets are not good candidates for debt financing because it is difficult to put them to an alternative use (Shleifer\&Vishny, 1991) and cannot be transferred to another industry when the industry they are employed in suffers an adverse shock. This measurement is expected to be negatively related to the collateral value of the assets (Titman \&Wessels, 1988).

- [pat3] the ratio of inventories to total assets; This measurement is expected to be negatively related to the collateral value of the assets. Although debts are used partly to finance inventories, and in most cases inventories maintain some value when the firm is liquidated, they do not serve as good collateral.

- [pat4] the ratio of receivables to total assets; Because of difficulties associated with the collecting receivables, including high collections costs, they are not good as collateral. (Asgharian, 1997). This ratio is expected to have negative effect on the collateral value of the assets.

The total revenue volatility [pev] is used as a proxy for a firm-specific risk. Since the focus of this Study is mostly 
non-publicly traded firms, we follow Morgan, Rime and Strahan (2004) to compute the time-varying measure of the firmspecific risk. We regress the firms' total revenue-to-total assets ratio on firm and year fixed-effects and then we use the absolute value of the residuals obtained from this regression as proxy for the firm-specific risk.

\section{Results and Discussion}

The data are collected from 26506 companies during the period from 2003 to 2012. Data are unbalanced and for $50 \%$ of companies, the data are available for a period of 7 years minimum.

Table 3. Number of Companies per Industry and Year

\begin{tabular}{|c|c|c|c|c|c|c|c|c|c|c|c|}
\hline Industry & 2003 & 2004 & 2005 & 2006 & 2007 & 2008 & 2009 & 2010 & 2011 & 2012 & Total \\
\hline A & 255 & 279 & 353 & 355 & 375 & 350 & 413 & 368 & 370 & 377 & 3.495 \\
\hline B & 14 & 13 & 17 & 13 & 14 & 15 & 17 & 12 & 14 & 15 & 144 \\
\hline C & 108 & 117 & 133 & 134 & 139 & 137 & 145 & 144 & 148 & 145 & 1.350 \\
\hline D & 2.961 & 3.062 & 3.328 & 3.567 & 3.672 & 3.473 & 3.537 & 3.358 & 3.392 & 3.399 & 33.749 \\
\hline E & 74 & 75 & 90 & 100 & 110 & 108 & 132 & 150 & 148 & 145 & 1.132 \\
\hline F & 1.316 & 1.365 & 1.469 & 1.579 & 1.639 & 1.542 & 1.583 & 1.454 & 1.464 & 1.456 & 14.867 \\
\hline G & 6.058 & 6.419 & 7.164 & 7.686 & 7.891 & 7.306 & 7.589 & 6.900 & 6.996 & 6.922 & 70.931 \\
\hline H & 417 & 437 & 477 & 514 & 524 & 486 & 515 & 489 & 485 & 499 & 4.843 \\
\hline I & 1.301 & 1.342 & 1.445 & 1.561 & 1.594 & 1.548 & 1.552 & 1.520 & 1.528 & 1.525 & 14.916 \\
\hline J & 46 & 56 & 67 & 78 & 84 & 97 & 98 & 88 & 85 & 87 & 786 \\
\hline K & 1.624 & 1.727 & 1.952 & 2.148 & 2.328 & 2.343 & 2.570 & 2.500 & 2.551 & 2.620 & $\mathbf{2 2 . 3 6 3}$ \\
\hline M & 94 & 95 & 137 & 111 & 113 & 118 & 185 & 125 & 124 & 129 & 1.231 \\
\hline N & 64 & 65 & 221 & 77 & 85 & 75 & 217 & 101 & 102 & 110 & 1.117 \\
\hline O & 326 & 337 & 418 & 415 & 444 & 405 & 492 & 458 & 466 & 473 & 4.234 \\
\hline Total & 14.658 & 15.389 & 17.271 & 18.338 & 19.012 & 18.003 & 19.045 & 17.667 & 17.873 & 17.902 & 175.158 \\
\hline
\end{tabular}

Under the assumption that proposed regressors/independent variables are exogenous, estimation of dynamic panel models are conducted using the two step Generalized Method of Moments (GMM) through xtabond2 formula in STATA, as proposed by Roodman (2009).

Dynamic panel models are developed for entire sample and subdivided by each industry. Each dynamic panel model is tested against the existence of serial correlations with residuals using the Arellano-Bond test and if the instruments are exogenous using the Sargan/Hansen test of over identifying restrictions. All two models at the level of entire sample (as including some industries) perform rather poorly against Arellano Bond test and Sargan/Hansen test indicating issues with serial correlations and endogenity of instruments.

In the first Dynamic panel model with Financial Leverage - Debt to Capital Ratio= Debt/(Debt +Equity), only industries $\mathrm{C}, \mathrm{M}$ and $\mathrm{N}$ don't have serial correlations significant. Instruments in all industries have issues with proposed exogenity of independent variables.As presented in the Table 4 in the Dynamic panel model with Balance-sheet Leverage - Total liabilities to assets= Total Liabilities/Total assets per most of industries don't have problems with serial correlations (except for industry $K$, and total sample model) where industries $A, B, C, E, H, K$, and $M$ don't have issues about endogenity of instruments.

Applied remedies to improve serial correlations and endogenity (higher lags, changing variable lists from iv style to gmm) yields no better results. Both dynamic panel data models are statistically significant at the level of entire sample and per industry. But since the post estimation tests within the first panel model (financial leverage), do not yield the required levels, it is going to be left out from the further discussion. The dynamic panel model as describe above do not fully respond to data and should be further analyzed using other dynamic panel data models and/or using the balanced sample. In this Study, we will focus only on the results of the Dynamic panel model with Balance-sheet Leverage since the post-estimations tests are met by most of industries and therefore can be generalized.

The proposed dynamic panel model (balance-sheet leverage) of the capital structure fails to provide a model that describes capital structure change for the entire sample, due to remaining serial correlation between regressors and residuals and their endogenity, but does succeed in providing a model of the firm-level determinants for most industries. The results confirm the view that differences in industry characteristic lead to an inter-industry variation in the capital structure. We observe differences in the basic capital structure of firms in our sample attributable to firm-specific characteristics. 
The number of analyzed companies working at the agriculture, hunting and forestry industry (A) over the period of ten years is 2238. The study found that only profitability and asset tangibility is the statistically significant leverage predictor for this industry. Profitability, measured with ROA, has a negative influence on leverage. The nexus between asset tangibility and leverage is dependent on how the latter is defined. We document that ratio of tangible and intangible asset to total assets negatively influences leverage whether the ratio of accounts receivable to total assets has a positive influence on leverage. The number of analyzed companies in the fishing industry (B) over the years varies from 10 to13. Although the results are statistically significant and post-estimation tests are satisfactory, due to low number of companies further analysis is not completed for fishing industry.

The number of analyzed companies in the mining industry (C) over the ten years amounts to 882 . We find a robustly significant and inverse relationship between profitability and the capital structure. The results also relieved a negative relationship between the asset structure measured by tangible assets and the capital structure choice.The number of analyzed companies in the production and distribution of electric energy, gas and water industry $(\mathrm{E})$ is 701. Among all the firm-level variables, only profitability (ROE) is observed to have a negative relationship with the leverage.

Table 4. Dynamic Panel Model - Balance sheet Leverage

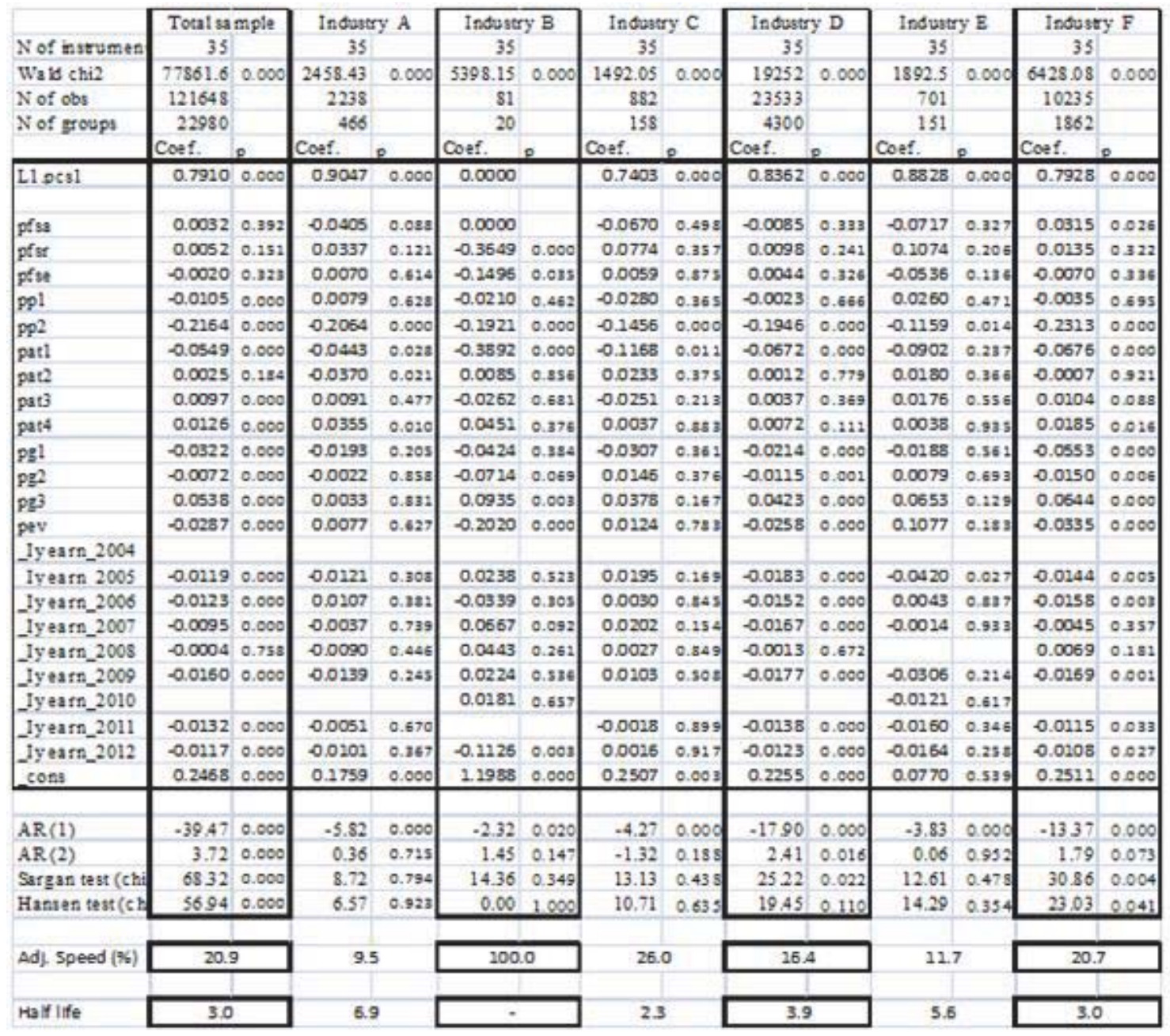




\begin{tabular}{|c|c|c|c|c|c|c|c|c|c|c|c|c|c|c|c|}
\hline \multirow{2}{*}{\multicolumn{2}{|c|}{ Industry G }} & \multicolumn{2}{|c|}{ Indestry H } & \multicolumn{2}{|c|}{ Industy I } & \multicolumn{2}{|c|}{ Indusery J } & \multicolumn{2}{|c|}{ Industy $\mathrm{K}$} & \multicolumn{2}{|c|}{ Industry $\mathrm{M}$} & \multicolumn{2}{|c|}{ Industy $\mathrm{N}$} & \multicolumn{2}{|c|}{ Industry 0} \\
\hline & & 35 & & 35 & & \multicolumn{2}{|c|}{35} & 35 & & \multicolumn{2}{|l|}{35} & \multicolumn{2}{|l|}{35} & \multicolumn{2}{|l|}{35} \\
\hline 41314.6 & $0.00 \mathrm{~d}$ & 47132 & 0.000 & 5183.48 & 0.000 & 547.54 & $0.00 \mathrm{~d}$ & 7611.21 & 0.000 & 1099.09 & 0.000 & 855.56 & 0.000 & 2018.66 & 0.000 \\
\hline 49655 & & 3233 & & 10492 & & 533 & & 15766 & & 800 & & 599 & & 2900 & \\
\hline 9381 & & 667 & & 1920 & & 124 & & 3077 & & 171 & & 109 & & 574 & \\
\hline Coet. & - & Coef. & D. & Coef. & 2 & \multicolumn{2}{|c|}{ Coef. $:$} & Coef. & $=$ & \multicolumn{2}{|c|}{ Coef. } & \multicolumn{2}{|l|}{ Coef. } & Coef. & $=$ \\
\hline 0.7343 & 0.000 & 0.7871 & 0.000 & 0.7509 & 0.000 & 0.3232 & 0.000 & 0.7635 & 0.000 & 0.8127 & 0.000 & 0.8471 & 0.000 & 0.8353 & 0.000 \\
\hline-0.0042 & 0.462 & 0.0194 & $0.36=$ & 0.0117 & 0.385 & 0.1413 & 0.101 & 0.0553 & 0.000 & 0.0404 & 0.448 & -0.0614 & 0.149 & -0.0204 & 0.428 \\
\hline 0.0094 & 0.101 & 0.0020 & 0.823 & 0,0002 & 0.990 & 0.0495 & 0.451 & 0.0094 & 0.138 & $-0,0559$ & $0.34 c$ & -0.0896 & 0.071 & 0.0380 & 0.247 \\
\hline-0.0050 & 0.092 & 0.0015 & 0.899 & 0.0028 & 0.704 & 0.0412 & 0.227 & 0.0067 & 0.275 & 0.0249 & 0.446 & 0.1090 & 0.002 & -0.0017 & 0.911 \\
\hline-0.0102 & 0.014 & 0.0347 & 0.015 & -0.0273 & 0.000 & 0.0494 & $0.25 \mathrm{~s}$ & 0.0151 & 0.108 & -0.0599 & 0.077 & 0.0211 & $0.44 \mathrm{~s}$ & 0.0085 & 0.548 \\
\hline-0.2233 & 0.000 & 0.1885 & 0.000 & -0.2091 & 0.000 & 0.2282 & 0.000 & 0.2259 & 0.000 & -0.2796 & 0.000 & -0.1595 & 0.000 & -0.2625 & 0.000 \\
\hline-0.0462 & 0.000 & 0.0861 & 0.003 & -0.0615 & 0.000 & 0.0090 & 0.853 & 0.0480 & 0.000 & 0.0010 & 0.972 & -0.0764 & 0.067 & -0.0423 & 0.069 \\
\hline 0.0095 & 0.001 & 0.0069 & 0.604 & -0.0156 & 0.052 & 0.0452 & 0.223 & 0.0037 & 0.498 & -0.0653 & 0.120 & -0.0736 & 0.020 & 0.0002 & 0,597 \\
\hline 0.0102 & 0.003 & 0.0224 & 0.041 & 0.0074 & 0.213 & 0.0049 & 0.936 & 0.0111 & 0.080 & -0.0070 & 0.807 & 0.0208 & 0.320 & 0.0000 & 0.997 \\
\hline 0.0172 & 0.000 & 0.0062 & 0.564 & -0.0166 & 0.028 & 0.0151 & 0.608 & 0.0134 & 0.026 & 0.0112 & $0.66 \mathrm{C}$ & 0.0332 & 0.230 & 0.0080 & 0.579 \\
\hline-0.0311 & 0.000 & 0.0025 & 0.246 & -0.0288 & 0.000 & 0.0910 & 0.075 & 0.0553 & 0.000 & -0.0251 & 0.243 & 0.0299 & 0.228 & -0.0375 & 0.011 \\
\hline-0.0036 & 0.152 & 0.0199 & 0.021 & -0.0072 & 0.153 & 0.0068 & 0.85 .1 & 0.0129 & 0.005 & -0.0151 & 0.411 & -0.0488 & 0.078 & 0.0007 & 0.941 \\
\hline 0.0516 & 0.000 & 0.0192 & 0.157 & 0.0846 & 0.000 & 0.1752 & 0.000 & 0.0562 & 0.000 & 0.0475 & 0.032 & -0.0053 & 0.864 & 0.0329 & 0.035 \\
\hline-0.0255 & 0.000 & 0.0631 & 0.000 & -0.0230 & 0.001 & 0.0605 & 0.041 & 0.0269 & 0.000 & -0.0360 & 0.254 & -0.0512 & 0.024 & -0.0412 & 0.002 \\
\hline-0.0170 & 0.000 & & & & & 0.0016 & 0.967 & & & -0.0194 & 0.340 & 0.0597 & 0.026 & 0.0219 & 0.012 \\
\hline-0.0151 & 0.000 & 0.0040 & 0.576 & -0.0007 & 0.853 & & & 0.0046 & 0.333 & -0.0823 & 0.002 & 0.0305 & 0.536 & -0.0189 & 0.042 \\
\hline-0.0120 & 0.000 & 0.0019 & 0.785 & 0.0023 & 0.634 & 0.0078 & $0.81 \mathrm{~s}$ & 0.0008 & 0.852 & -0.0565 & 0.013 & 0.0716 & 0.007 & $-0,0001$ & 0.987 \\
\hline-0.0003 & 0.893 & 0.0041 & $0.58 \mathrm{c}$ & 0,0021 & 0.666 & 0.0083 & 0,203 & 0.0029 & 0.497 & & & & & & \\
\hline-0.0215 & 0.000 & 0.0025 & 0.731 & -0.0071 & 0.132 & 0.0360 & 0.253 & 0.0106 & 0.013 & -0.0470 & 0.020 & 0.0527 & 0.204 & 0.0134 & 0.230 \\
\hline & & 0.0091 & $0.29 \mathrm{~B}$ & 0.0053 & 0.305 & 0.0006 & 0.985 & 0.0022 & 0.627 & -0.0222 & $0.28 c$ & 0.0550 & 0.032 & 0.0070 & 0.481 \\
\hline-0.0152 & 0.000 & 0.0099 & 0.224 & -0.0044 & 0.366 & 0.0583 & 0.213 & 0.0108 & 0.012 & -0.0544 & 0.008 & 0.0570 & 0.014 & -0.0026 & 0.735 \\
\hline-0.0131 & 0.000 & 0.0095 & 0.242 & -0.0071 & 0.133 & 0.0041 & 0.906 & 0.0068 & 0.210 & -0.0829 & 0.000 & 0.0562 & 0.023 & -0.0013 & 0.875 \\
\hline 0.2459 & 0.000 & 0.2720 & 0.000 & 0.2668 & 0.000 & 0.2414 & $0.01 \mathrm{a}$ & 0.2568 & 0.000 & 0.3130 & 0.000 & 0.1917 & 0.041 & 0.2404 & 0.000 \\
\hline-2434 & $0.00 \mathrm{~d}$ & -6.91 & 0.000 & -11.90 & 0.000 & -2.00 & 0.046 & -14.35 & 0.000 & -3.98 & 0.006 & -4.67 & 0.000 & -6.59 & 0.000 \\
\hline 1.14 & 0.254 & -0.07 & 0.941 & 0.66 & 0.512 & 0.85 & 0.394 & 2.09 & 0.037 & 0.76 & 0.445 & 1.52 & 0.128 & -0.21 & 0.399 \\
\hline 49.07 & $0.00 \mathrm{~d}$ & 11.68 & 0.554 & 21.40 & 0.065 & 18.97 & 0.124 & 19.61 & 0.105 & 15.79 & 0.261 & 17.57 & 0.175 & 27.67 & 0.010 \\
\hline 3456 & 0.001 & 9.54 & 0.731 & 20.93 & 0.074 & 25.29 & 0.021 & 12.75 & 0.457 & 14.87 & 0.316 & 17.79 & 0.166 & 10.69 & 0.636 \\
\hline 21.6 & & 213 & & 24.9 & & 17.7 & & 23.6 & & 18. & & 15. & & 16. & \\
\hline & & & & & & & & & & & & & & & \\
\hline 2.9 & & 2.9 & & 2.4 & & 3.6 & & 2.6 & & 3.3 & & 4.2 & & 39 & \\
\hline
\end{tabular}

The number of analyzed companies in the accommodation and food service industry $(\mathrm{H})$ over the ten years is 10235 . The results suggest that four out of five analyzed firm-level variables are statistically significant for this industry. We found a strong negative relationship between profitability and leverage ratio. The estimated coefficients for our two profitability proxies are both statistically significant, though with bigger magnitudes when we use ROTA then ROA. We also find evidence that tangible assets are negatively related to the leverage while the ratio of inventories to total asset positively affects the leverage ratio. Another robust result is positive relationship between leverage and the growth rate measured by total revenue growth. The results demonstrate that riskier companies (measuring risk as the within-firm volatility of earnings) tend to be less total leveraged.

The number of companies in the real estate industry $(K)$ over the ten years has been 15766 . This is the only industry for which all firm-level determinants showed significant coefficients. The firm size, measured by total assets, has a positive relationship with the leverage ratio, which can be interpreted that larger firms (firms with larger total assets) have more access to outside financing in general. ROA as proxy for profitability document an inverse relationship with leverage. Asset composition measured by level of tangible assets available is negatively related to the leverage ratio while the same variable measure by the ratio of accounts receivable to the level of total asset is positively related to the leverage. All three proxies for growth opportunities are statistically significant predictors of total leverage but with inconsistent direction. There is a negative relationship between leverage and the growth rate, if the latter one is measured by the annual asset and total sales growth, while there is a positive relationship between the leverage ratio and growth opportunities measured as the size of the deviation from average growth of total revenue. Finally, the study indicates that risk variable negatively affects the leverage.

The number of companies in the education industry (M) over the years accounts for 800 . For companies operating in this industry we could find only two statistically significant firm-level determinants, the profitability and the growth opportunities. The first one is negatively while the second one is positively related to the leverage ratio.

Overall, the variation in the capital structure - total liabilities to assets is explained by 1st lag of the capital structure 
- total liabilities to assets, profitability (both regressors), assets tangibility (except for - the ratio of intangible assets to total assets), growth and earnings volatility.

A highest change in the capital structure - total liabilities to assets have companies with highest difference in the capital structure - total liabilities to assets in comparison with the previous year (change in 1 unit of difference, make app. $79 \%$ of unit increase in the capital structure - total liabilities to assets). The second highest change in the capital structure - total liabilities to assets have size of ROA, where for each positive change of ROA for 1 unit it is expected to have app. $22 \%$ of unit decrease in the capital structure - total liabilities to assets. Remaining significant repressors' affectthe change in the capital structure - total liabilities to assets from 1 to $5 \%$. In all models per industry change in ROA has negative relationships with change in the capital structure - total liabilities to assets and coefficients vary from -0.12 to -0.26 .

A consistent negative relationship with the capital structure - total liabilities to assets is in the ratio of tangible fixed assets to the total assets and earnings volatility. Remaining regressors have an inconsistent relationship with the capital structure - total liabilities to assets, mainly statistically insignificant. The results indicate that one-period lagged dependent variable (total liabilities to assets) has a significant and positive effect on leverage (except for the industry B),indicating the existence of adjustment to the target capital structure.

\section{Conclusion}

The research aimed at testing the validity of capital structure theories in the $\mathrm{FBiH}$. In this paper we have developed a model to explain firm characteristics (the micro-factors) determining the capital structure, measured by two dependent variables. We conducted our empirical analysis using an unprecedented database with non-financial firms from 14 different industries based in the $\mathrm{FBiH}$, spanning 10 years of data from 2003 through 2012. The data are strongly unbalanced, meaning that we allow firms to enter or leave the sample during the referred period, thus avoiding any survivorship bias. We examined the data using a dynamic panel System GMM estimator, which is robust to firm heterogeneity and data endogeneity problems.

The proposed dynamic panel models of the capital structure measured bythefinancial leverage fails to provide the models that describe the capital structure change, mostly due to remaining serial correlation between regressors and residuals and their endogenity. The proposed dynamic panel model of the capital structure measured by the balancesheet leverage fails to provide a model that describe the capital structure change for the entire sample, due to remaining serial correlation between regressors and residuals and their endogenity, but succeed to provide model of firm-level determinants at the industry level. The industry in which a firm operates seems to have an influence on the basic capital structure decisions of firms in our sample. We observe that the inter-industry differences appear to be a function of how the capital structure is defined. This signifies the role that the industry specific operating characteristics and regulations play in the firm's capital structure decisions.

The empirical analysis also investigates the dynamic behavior of the leverage ratios in our sample. We find that capital structure is highly persistent. Indeed, a lagged leverage is the best predictor of subsequent leverage in all regressions. So, the proposed regressors have statistically significant relationships with the capital structure of which most important is first lagged period of dependent the capital structure variable that explains most of explained variance of the capital structure, while profitability (ROA) follows as the next most important determinant of the capital structure. Assets tangibility, growth, firm size and earning volatility are statistically significant proxies of the capital structure, but with low effects on the capital structure change (2-7\%).

To examine the relationship between the profitability and capital leverage in the FBiH corporate sample, we find a strong and robust negative relationship between profitability and the leverage ratio, consistent with most of the extant empirical literature (Friend \& Lang, 1988; Rajan\&Zingales, 1995; Antoniou et al. 2008). Therefore, we evidenced that more profitable firms tend to have less leverage, while less profitable firms tend to have more leverage. Table 4 indicates that this inverse relationship persists even after accounting for the influence of industry. Thetrade-offtheory can be denied, which assumes a positive connection between the two factors- saying, that the profit making firm strive to utilize the interest taxshield via rising loans. This is in line with the pecking order hypothesis suggesting that a company's financing process - due to the asymmetric information and thus a high transaction costs, does follows a specific hierarchy-using first internal sources available, and only then resort to external finance; first debt and only as a last choice to equity. In other words, the evidence that more profitable firms tend to have less leverage while less profitable firms tend to have more leverage may also be interpreted as evidence of the firm's limited access to outside financing.

In the Study, we found inconsistent results for relationship between different proxies for growth opportunities and leverage. For the proxies based on the two years differences, whether in total assets or total revenue, the relationship was negative. That is in line with the trade-off theory and similar to the findings for developed countries (Banerjee, 
Hesmati, \&Wihlborg, 2004). But the positive correlation was found when the growth rate was measured as the coefficient of the trend, scaled by the book value of the total assets, from the regression of book value of total assets over ten years on a time trend, which supports the pecking order hypothesis rather than other theories.

The negative correlation of share of tangible assets and leverage is valid for the whole period, which is in line with the evidence from the previous studies (Cornelli, Portes\& Schaffer, 1996; Nivorozhkin, 2002). This is due to the dominance of short-term debt in total debt, which does not necessarily require collateral. The trade-off theory and the agency theory obviously didn't prevail in this period in FBiH. This means that the company with high fixed assets value should employ less debt in its capital structure components and it is vice versa. The company with low level of tangible assets seeks for external source of fund, in terms of short-term debt, which does not necessarily require collateral, or other forms of non-financial financing.

We have found the connection proposed by the theory between the volatility of earnings and the level of capital leverage. This type of risk negatively influences the liabilities/equity ratio significantly in the examined period. This suggests that firms appear to reduce their use of total debt in their capital structure when they face higher risks in their own business activities.

Neither positive nor negative relationship between the firm size and the capital leverage cannot be proved, expected for two industries. Those results are opposite with the assumption of the trade-off theory, agency theory and signaling approach of positive relationship existence as with the assumption of negative relationship made by pecking order theory. None of them could be proved from the FBiH corporate database.

Finally, the empirical evidence displayed in this Study finds it difficult to demonstrate the validity of the trade-off and pecking order theories as stand-alone models. This contradicts the standard academic view that they are mutually exclusive perspectives or models. The two models provide very different predictions as to what we should expect to observe empirically about financial leverage. However the employment of fairly flexible targets for financial gearing, accounts for this discrepancy between the theory and practice.

\section{References}

Antoniou, A., Guney, Y., \&Paudyal, K. (2008). The determinants of capital structure: capital- market oriented versus bank-oriented institutions. Journal of Financial and Quantitative Analysis, 43, 59-92.

Arellano, M., \&Bover, O. (1995).Another look at the instrumental variable estimation of error-components models.Journal of Econometrics, 68, 29-52.

Arellano, M., \& Bond, S. (1991). Some tests of specification for panel data: Monte Carlo evidence and an application to employment equations. Review of Economic Studies, 38(2), 277-297.

Asgharian, H. (1997). Essays on capital structure.Lund Economic Studies nr. 64. Doctoral Thesis, Department of Economics, Lund University, Sweden.

Banerjee, S., Heshmati, A., \&Wihlborg, C. (2004). The dynamics of capital structure.Research in Banking and Finance, 4(1), $275-297$.

Bessler, W., Drobetz, W., \&Kazemieh, R. (2011). Factors affecting capital structure decisions. In: Baker, H.K \& Martin, G.S. (eds.) Capital structure and corporate financing decisions: theory, evidence, and practice. New Jersey: John Wiley.

Blundell, R., \& Bond, S. (2000). GMM estimation with persistent panel data: an application to production functions. Econometric Reviews, 19, 321-340.

Blundell, R., \& Bond, S. (1998). Initial conditions and moment restrictions in dynamic panel data models.Journal of Econometrics, 87(1), $115-143$.

Bond, S. (2002). Dynamic panel data models: a guide to micro data methods and practice. Portuguese Economic Journal, 1, 141-162.

Bradley, M., Jarrell, G. \& Kim, H. (1984). On the existence of an optimal financial structure. Journal of Finance, 39, 857-78.

Castanias, R. (1983). Bankruptcy risk and optimal capital structure.Journal of Finance, 38, 1617-1635.

Chen, J. (2004). Determinants of capital structure of Chinese-listed companies. Journal of Business Research, 57, $1341-1351$.

Chang, C., Lee, A. C. \& Lee, C. F. (2009). Determinants of capital structure choice: a structural equation modeling approach. Quarterly Review of Economics and Finance,49, 197-213.

Clark, B. J., Francis, B. B. \& Iftekhar, H. (2009). Do firms adjust toward target capital structures? Some International Evidence. SSRN eLibrary. SSRN.

Cornelli, F., Portes R., \& Schaffer, M. (1996). The capital structure of firms in Central and Eastern Europe. CEPR Discussion Paper No. 1392, Centre for Economic Policy Research.

Fan, J., Titman, S., \& Twite, G. (2003). An international comparison of capital structure and debt maturity choices. Working Paper, Hong Kong School of Business and Management.

Flannery, M., \&Hankins,K. (2007).A theory of capital structure adjustment speed.Working paper.

Flannery, M., \&Rangan, K. (2006).Partial adjustment toward target capital structures.Journal of Financial Economics, 79(3), 469-506.

Frank, M., \&Goyal, V. (2009). Capital structure decisions: which factors are reliably important?.Financial Management, 38(1), 1-37.

Friend, I., \& Lang, L. (1988).An empirical test of the impact of managerial self-interest on corporate capital structure.Journal of Finance, 
43, 271-281.

Gaud, P., Jani, E., Hoesli, M. \& Bender, A. (2005). The capital structure of Swiss companies: an empirical analysis using dynamic panel data. European Financial Management.11, 51-69.

Graham, J. (2000). How big are the tax benefits of debt?.Journal of Finance, 55, 1901-1941.

Hansen, L. (1982). Large sample properties of generalized method of moments estimators. Econometrica, 50, 1029-1054.

Kester, C. (1986). Capital and ownership structure: a comparison of United States and Japanese manufacturing corporations. Financial Management, 15, 5-16.

Kim,W., \& Sorensen, E. (1986). Evidence on the impact of the agency costs of debt on corporate policy. Journal of Financial and Quantitative Analysis, 21(2), 131-143.

Lemmon, M., Roberts, M., \&Zender, J. (2008). Back to the beginning: persistence and the cross-section of corporate capital structure. Journal of Finance, 63, 1575-1608.

Modigliani, F., \& Miller, M. (1958). The cost of capital, corporation finance, and the theory of investment. American Economic Review, 48(3), 655-669.

Morgan, D., Rime, B, \&Strahan, P. (2004).Bank integration and state business cycles. The Quarterly Journal of Economics, MIT Press, 119(4), 1555-1584.

Nivorozhkin, E. (2002). Capital structures in emerging stock market: the case of Hungary. The Developing Economies Volume, 40(2), 166-187.

Ooi, J. (1999). The determinants of capital structure: evidence on UK property companies. Journal of Property Investment \& Finance, 17(5), $464-480$.

Ozkan, A. (2001). Determinants of capital structure and adjustment to long run target: evidence from UK company panel data set. Journal of Business Finance \& Accounting, 28, 175-198.

Padron Y., Apolinario R., Santana O., Conception, M., Martel V., \& Sales, L. (2005). Determinant factors of leverage: an empirical analysis of Spanish corporations. Journal of Risk Finance, 6(1), 60-68.

Rajan, R., \&Zingales, L. (1995). What do we know about capital structure? Journal of Finance, 50(5), 1421-1460.

Roodman, D. (2009). How to do xtabond2: an introduction to difference and system GMM in Stata. Stata Journal, StataCorp LP, 9(1), 86-136.

Shamshur, A. (2012). Essays on capital structure stability. Center for Economic Research and Graduate Education Charles University Prague

Shleifer, A., \&Vishny, R. (1991). Takeovers in the '60s and '80s: evidence and implications. Strategic Management Journal, 12, 51-59.

Shyam-Sunder, L., \& Myers, S. (1999). Testing static trade-off against pecking order models of capital structure. Journal of Financial Economics, 51, 219-244.

Talberg, M., Winge, C., Frydenberg, S., \& Westgaard, S. (2008). Capital Structure across Industries. International Journal of the Economics of Business, 15(2), 181-200.

Titman, S., \&Wessels, R. (1988). The determinants of capital structure.Journal of Finance, 43(1), 1-19.

Welch, I. (2011). Two common problems in capital structure research: the financial-debt-to-asset ratio and issuing activity versus leverage changes. International Review of Finance, 11(1), 1-17.

Wiwattanakantang, Y. (1999). An empirical study on the determinants of the capital structure of Thai firms.Pacific-Basin Finance Journal, Elsevier, 7(3-4), 371-403. 